$12-2010$

\title{
The River Discontinuum: Applying Beaver Modifications to Baseline Conditions for Restoration of Forested Headwaters
}

Denise Burchsted

University of Connecticut, dburchsted@keene.edu

Melinda Daniels

Kansas State University

Robert Thorson

University of Connecticut - Storrs

Jason Vokoun

University of Connecticut - Storrs

Follow this and additional works at: https://opencommons.uconn.edu/geosci

Part of the Environmental Engineering Commons, Geomorphology Commons, $\underline{\text { Hydrology }}$ Commons, Natural Resources and Conservation Commons, Physical and Environmental Geography Commons, Terrestrial and Aquatic Ecology Commons, and the Water Resource Management Commons

\section{Recommended Citation}

Burchsted, Denise; Daniels, Melinda; Thorson, Robert; and Vokoun, Jason, "The River Discontinuum: Applying Beaver Modifications to Baseline Conditions for Restoration of Forested Headwaters" (2010). Center for Integrative Geosciences. 1.

https://opencommons.uconn.edu/geosci/1 


\title{
The River Discontinuum: Applying Beaver Modifications to Baseline Conditions for Restoration of Forested Headwaters
}

\author{
DENISE BURCHSTED, MELINDA DANIELS, ROBERT THORSON, AND JASON VOKOUN
}

\begin{abstract}
Billions of dollars are being spent in the United States to restore rivers to a desired, yet often unknown, reference condition. In lieu of a known reference, practitioners typically assume the paradigm of a connected watercourse. Geological and ecological processes, however, create patchy and discontinuous fluvial systems. One of these processes, dam building by North American beavers (Castor canadensis), generated discontinuities throughout precolonial river systems of northern North America. Under modern conditions, beaver dams create dynamic sequences of ponds and wet meadows among free-flowing segments. One beaver impoundment alone can exceed 1000 meters along the river, flood the valley laterally, and fundamentally alter biogeochemical cycles and ecological structures. In this article, we use hierarchical patch dynamics to investigate beaver-mediated discontinuity across spatial and temporal scales. We then use this conceptual model to generate testable hypotheses addressing channel geomorphology, natural flow regime, water quality, and biota, given the importance of these factors in river restoration.
\end{abstract}

Keywords: fluvial geomorphology, hierarchical patch dynamics, stream ecology, river continuum concept, river restoration

\section{$\mathbf{P}$} rivate and public agencies across the United States spend billions of dollars on river restoration (Bernhardt et al. 2005) in attempts to return targeted systems to a state similar to that before disturbance. Our understanding of the predisturbance system, however, is framed by recent human alterations (e.g., Walter and Merritts 2008). To successfully implement a project that achieves even partial restoration, it is essential to understand the baseline conditions (Wohl 2005).

The baseline typically used in river restoration is a continuous, free-flowing system (FISRWG 1998). However, in catchments with limited modern human impact, the presumed continuity of headwaters is fragmented by bedrock, colluvium, large wood, past glacial souring and deposition, and North American beaver (Castor canadensis) dams (Naiman et al. 1988, Ballantyne 2002, Benda et al. 2005), among other discontinuities. These components increase longitudinal heterogeneity by generating a stepped channel-bed profile in place of the continuous slope of the reference condition, with shallower gradients, slower velocities, and the accumulation of sediment upstream of blockages, and with scouring downstream of them. River discontinuities increase lateral heterogeneity by maintaining upstream floodplains, scouring additional downstream channels, and causing channel avulsions.
River obstructions and their impacts also vary over time, with the temporal scale depending on the type of discontinuity. Bedrock discontinuities are created and destroyed at the longest time scale. Glacial scouring and deposition occurs within the temporal and spatial discontinuities set by bedrock. Following glacial retreat, paraglacial modification continues for tens of thousands of years (Ballantyne 2002). Sediment, debris, and beaver dams modify the river corridor at a still smaller scale, with creation and destruction by stochastic events such as fire and floods (Benda et al. 2004) and beaver activity, and time scales of persistence as short as years to decades.

These discontinuities have been largely removed from rivers in the United States through recent human activities such as bedrock blasting, debris-dam removal, other channel homogenization for log drives, placer mining, logging of forests that once supplied major debris dams, beaver trapping, and floodplain reclamation (Lichatowich 1999, Wohl 2005). Many of the remaining preexisting discontinuities have been modified-and new ones created-by human dam and road construction. For example, table 1 compares beaver dams with run-of-the-river human dams; run-of-the-river dams are the most common existing and removed dams in the United States (Poff and Hart 2002). However, rather than viewing 
human discontinuities as modifications of preexisting ones, restoration efforts typically view human dams and roads as features that disrupt otherwise continuous systems.

Recent beaver recolonization provides an opportunity to examine one of the major discontinuities once present in rivers. Beavers create a shifting mosaic (sensu Stanford et al.
2005) of free-flowing, impounded, and meadow habitats (see examples in figure 1), the last two of which can dominate a river network (Naiman et al. 1988). Of these, beaver impoundments have been well studied at the reach and segment scale. When compared with a modern free-flowing reference, they alter hydrologic and sediment transport

\begin{tabular}{lll}
\hline $\begin{array}{l}\text { Table 1. Comparison of beaver and run-of-the river human dams as an example of human-built replacement of one type } \\
\text { of preexisting discontinuity along the river corridor. }\end{array}$ \\
\begin{tabular}{lll}
\hline Parameter & Run-of-the-river human dam & Intact beaver dam \\
\hline Permeability & Impermeable & Leaky or somewhat permeable \\
Structure longevity & 100 to 1000 years & 10 to 100 years \\
Number of spillways or downstream channels & One & One or more \\
Crest geometry & Simple, usually linear & Complex, irregular \\
Hydraulic cross section at the spillway crest & Uniformly fast and shallow & Variable, with concentrations of faster and \\
& & deeper water, often with multiple spillways; flow \\
& may be entirely through the dam \\
Low-flow water passage & Little to no release & Water continues to leak through dam \\
Upstream water level variability & Little to none & Variable over the water year \\
Upstream littoral zone & Narrow & Wide
\end{tabular} \\
\hline
\end{tabular}

Note: Run-of-the-river dams are the most common existing and removed dam type in the United States (Poff and Hart 2002). Source: Müller-Schwarze and Sun 2003, Burchsted et al. 2009.
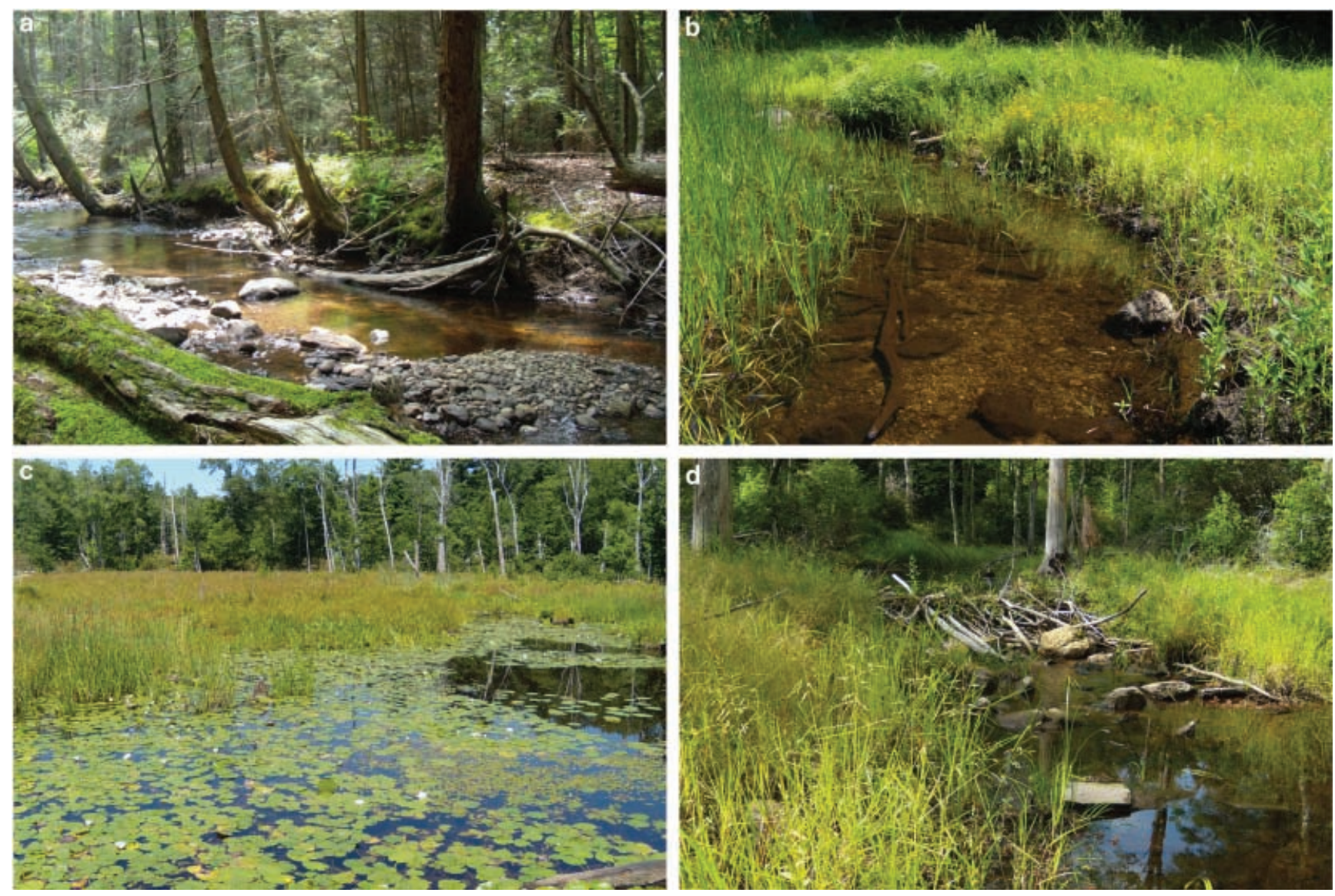

Figure 1. Examples of headwater segment types classified in this article: (a) free flowing, (b) beaver meadow, (c) valley beaver impoundment, and (d) in-channel beaver impoundment. 
regimes (cf. Pollock et al. 2003), biogeochemical cycles (Correll et al. 2000), and habitats (cf. Rosell et al. 2005).

Although beaver impoundments are well studied, little research has been conducted on the role of beaver meadows in catchment processes, although these features may be dominant in the headwater network (see discussion below). Additionally, the literature does not examine the cumulative, serial impacts (sensu Ward and Stanford 1983) of beaver-generated discontinuities. This lack of research is in spite of the density of beaver dams reaching 3 per 100 meters $(\mathrm{m})$ locally (Burchsted et al. 2009) and 10 per kilometer at larger scales (Pollock et al. 2003), and despite the importance of understanding processes at large scales for effective restoration (Palmer 2009). Additionally, understanding of the effects of beaver dams has not yet been applied to the many enterprises of river restoration, despite the impact of these dams on the processes targeted for restoration. Lastly, beaver dams are one of the many types of discontinuities altering river networks, and we use them in this article as a ubiquitous and well-defined example. We need to scale up our understanding of fluvial discontinuity to add additional information to the body of literature, and to apply this research to river restoration design.

This article presents a framework to guide future research by considering beaver-created features in headwaters. Headwater streams up to the fourth order in size account for $60 \%$ to $80 \%$ of miles in a river network (Benda et al. 2005). Because they control the sediment supply and strongly influence the biotic diversity of river networks (Meyer et al. 2007), they are important for restoration. In order to incorporate discontinuity into the headwater restoration baselines at appropriate scales, we present a discontinuous, hierarchical, patch-dynamics conceptual model (sensu Wu and Loucks 1995, Poole 2002).

In this model, beaver impoundment and meadow habitats are patches generated by the physical discontinuities of intact and breached beaver dams, respectively. These patches store and release water and sediments - with storage or release depending on the habitat type, season, and climatic conditions-resulting in a stepped longitudinal profile of the flux of these materials. Beaver dams may also limit organism movement, and they generate discontinuities in the longitudinal oxygen profile that modify biogeochemical cycling along the river corridor.

To apply the concept of longitudinal discontinuity to river restoration, we first consider the existing reference condition most commonly used in restoration design. We then describe the theoretical stream ecology literature beyond the river restoration reference, and build on the body of literature to create our conceptual model. Finally, we use our model to generate testable hypotheses that can guide future research, focusing on the major processes addressed by river restoration. We conclude by describing potential specific applications in restoration projects.

\section{Current river restoration view of headwaters}

River restoration priorities and designs commonly view rivers as equilibrium systems determined by local physical conditions, stripped of the complexities of multiple possible equilibrium states created by biological — particularly human —influences at scales beyond the site (Palmer 2009). The common practice of basing restoration design on physical reach-scale reference conditions is founded in this misperception. These reference conditions are derived from the river continuum concept (RCC; Vannote et al. 1980) and the longitudinal profile zones described by Schumm (1977), generating the vision of a continuous, freeflowing river (FISRWG 1998). Therefore, reference headwaters are narrow water bodies with higher gradients, larger mineral sediments, higher water velocities, organic matter dominated by terrestrial inputs, and a nearly closed forest canopy, and they are part of a continuous gradient from headwaters to mouth.

An example of reference-based restoration is shown in figure 2, a previously impounded reach shown one day after dam removal. In this case, a reference reach was selected from the same watercourse and the sediment impounded by the dam was removed as needed to create a channel as similar as possible to the reference-a common design practice (Pizzuto 2002). Additional design factors included channel and bank stability, longitudinal connectivity, and hydraulic conditions favorable for fish passage.

In comparison, the analogous beaver dam failure creates a beaver meadow, where the channel cross section is visibly narrower and deeper than the upstream or downstream reference on the same river (figure 1b). Since the channel in the meadow erodes out of previously impounded sediments, the bed is generally finer in size than the reference. Scattered cobbles on the bed surface, the result of bed coarsening, demonstrate the trajectory of the channel as it transitions to a state similar to the reference. Although the channel is actively eroding, most of the impounded sediments remain vegetated in place in the riparian zone.

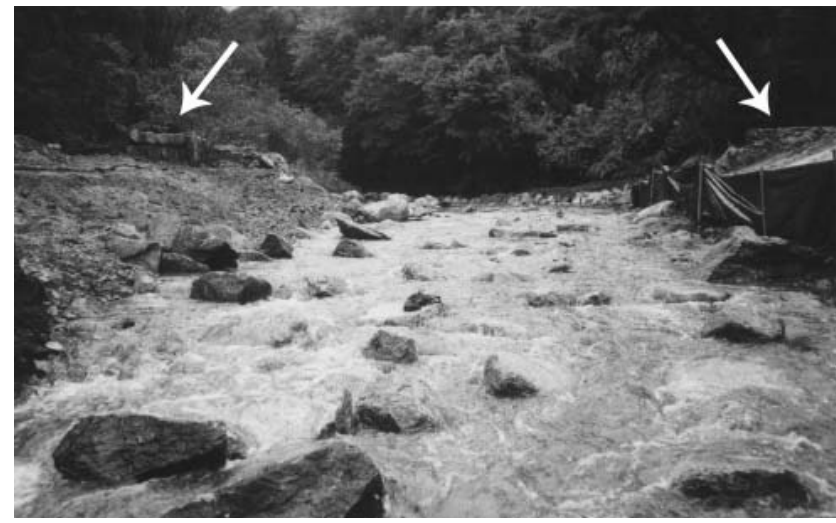

Figure 2. Example of a dam removal approximately one week following removal. View is facing upstream from within the area of the removed dam. White arrows mark the remaining abutments of the original dam face. The channel has been created by removing impounded sediment to match the shape of a downstream reference reach. Cobble substrate placed on the streambed will resist erosion in accordance with sediment transport theory. The banks are cut to a stable slope, stabilized at the base with large cobbles, and seeded with native vegetation. Compare with the channel in figure $1 b$. 
Without valuing one system over the other, we note that these two channels are fundamentally different. The differences can be traced in part to the emphasis of human dam removal on longitudinal connectivity of water and sediment. In contrast, beaver dam failure creates a relatively small breach in the dam; the remaining dam structure continues to impede high flows, and the eroding channel provides a source of sediment. Additional disparities in channel form are caused by differences in the discontinuity of the barriers before removal or failure (table 1). In order to select the appropriate reference condition for dam removal, it is necessary to understand the role of these different reach types at the catchment scale.

The issue of scale is further apparent when considering the common assumption that increasing heterogeneity at the reach scale increases species diversity, a belief that is largely unfounded (Palmer et al. 2010). The failure of this assumption in practice can be traced, in part, to its application at the incorrect scale. When scale is increased and multiple habitat types are included at the network scale, species diversity increases (Wright et al. 2002), but this understanding has not been applied to river restoration.

\section{The forested headwater paradigm}

In addition to providing a foundation for river restoration design, the RCC has generated decades of research and theoretical advances. The longitudinal gradient of the RCC has been expanded to allow for lateral (Junk et al. 1989) and subsurface (Stanford and Ward 1993) continuity, and has given way in part to longitudinal discontinuity generated by geologic features and physical processes (Montgomery 1999, Benda et al. 2004). Discontinuity creates patches, and relatively homogenous, distinct patches with clear boundaries interact longitudinally, laterally, and vertically (Pringle et al. 1988). Additional work has recognized that different processes dominate at various scales of time and space, resulting in the concept of hierarchical scaling of the river network (Frissell et al. 1986).

Superimposed on this patchy, heterogeneous morphology, organism actions and responses also control geomorphology and greatly increase patch heterogeneity through means beyond pure physical control over processes (Naiman and Rogers 1997). Of the many organisms that modify their environments, beavers influence channel morphology and biogeochemistry so dramatically that they inspired the
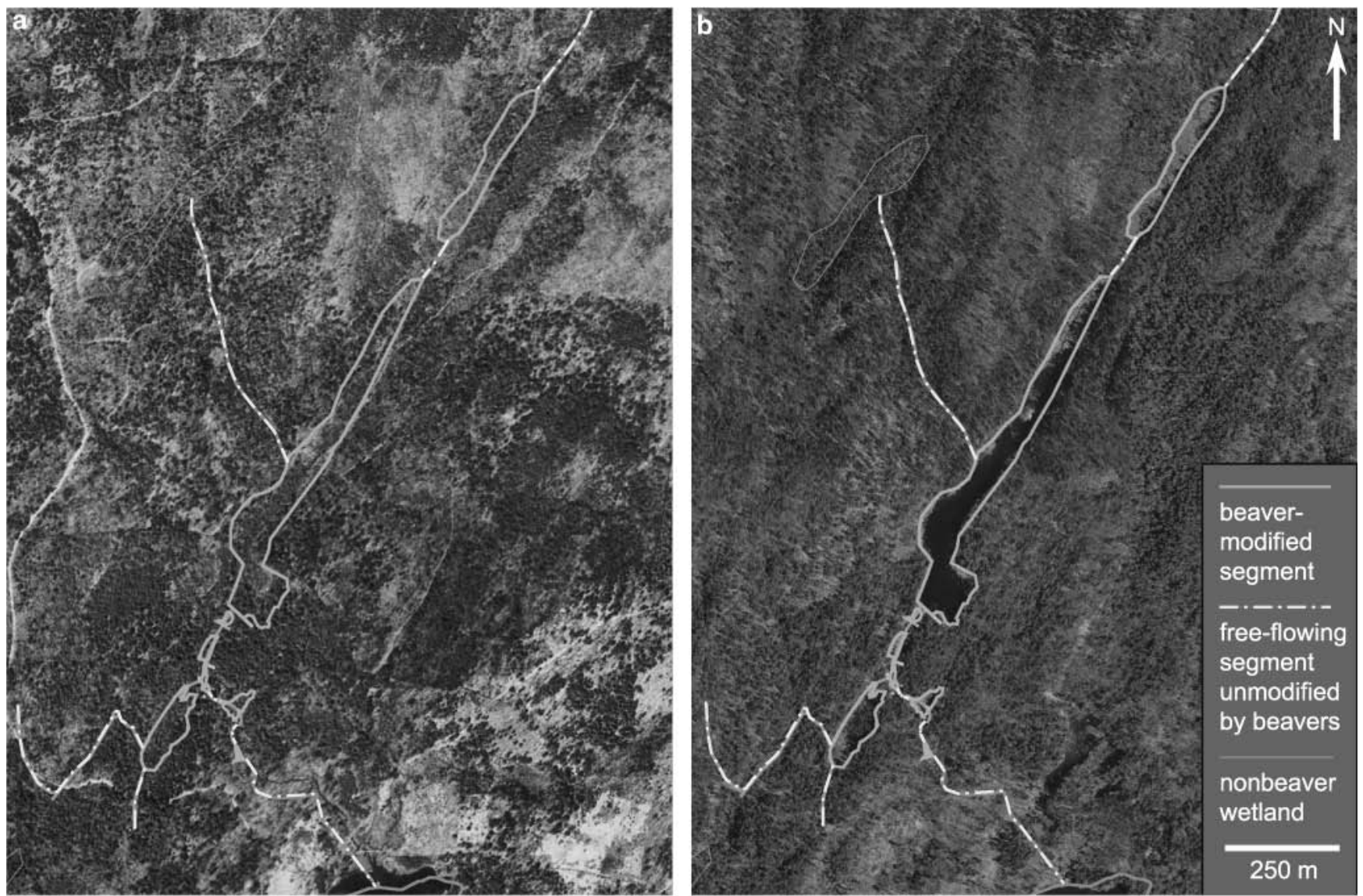

Figure 3. An example of beaver modification of a temperate forested headwater stream. Branch Brook in Union, Connecticut, a first-through third-order watercourse in this view, shown before and after beaver colonization. Flow is to the man-made lake at the southern boundary of this view. (a) A 1934 aerial photograph overlaid with segment types identified in the field in 2007 and 2008. (b) Late 1990s aerial photograph with 2007-2008 segments. Beaver-modified segments include both beaver impoundments and meadows. 
paradigm of the "ecosystem engineer" (Jones et al. 1994). Further, they dominated the precolonial headwaters of North America north of the Mexican border, with a range that excluded only the arid deserts of the US West, the Florida peninsula, and the arctic tundra. They constructed at least 25 million dams prior to European colonization, with modern dam densities of 10 per kilometer and more in areas with limited modern human influence (Pollock et al. 2003).

Despite their former success, beavers are absent from much of their historic range, and the impacts of their constructed features are missing from the RCC. The North American fur industry systematically eradicated beavers, with extirpations beginning on the East Coast in 1675 and proceeding westward (Thorson 2009). In the 20th century, state wildlife agencies successfully reintroduced beavers (e.g., CTDEP 2000), providing an opportunity to better understand this component of the precolonial fluvial system.

An example of the extent of beaver-created modifications can be seen in figure 3. Before recolonization, the valley bottom consisted of a densely forested riparian corridor, with no stream channel visible from the air. In contrast, the valley bottom after beaver colonization is a discontinuous, longitudinal juxtaposition of patches with extensive impoundments, meadows, and free-flowing segments. Inspection of historic aerial photos and of dead wood in the impoundments revealed that preimpoundment riparian trees were similar in size to the adjacent upland forest. The extent of river modification by beaver in this example is similar to other examples in the literature (e.g., Naiman et al. 1988).

\section{The river discontinuum}

Beaver dams are just one type of the many longitudinal discontinuities that can be found along the river corridor, all of which partially decouple downstream water and sediment transport, and in some cases also act as barriers to organism movement. Stanford and Ward (1993) described the subsurface hydrologic impact of the geologic discontinuities responsible for beaded valley morphology. Additional in-stream features can be viewed in the context of a gradient that ranges from fully continuous to fully discontinuous (see figure 4 for examples). Although this article describes intact and failed beaver dams as discontinuous, we do not intend to suggest an absolute condition but rather to describe the overall tendency in contrast with the continuous reference condition.

Using the example of beaver dams, table 2 shows how longitudinal decoupling can manifest as spatially and temporally variable storage and release of water and sediment, creating steps within the longitudinal profile of sediment and water flux. Additionally, these longitudinal discontinuities typically correspond with greater upstream lateral connectivity of water and sediment (Kondolf et al. 2006). The resulting patchy distribution of biogeochemical regimes and of habitats along the stream corridor corresponds with the longitudinal discontinuities.

Since the RCC cannot accommodate this level of complexity, a new reference paradigm is required. As described by Poole (2002), hierarchical patch dynamics (HPD) accommodate the patchy discontinuity of river networks at appropriate scales. When using this perspective, the riverscape at any given scale is broken into three-dimensional patches. A patch (encompassing element) at one scale can be divided into smaller patches (component elements) at finer scales, allowing for contextual, or top-down, processes. Component elements at the same scale are linked by within-scale processes. A series of component elements can affect the encompassing element, which allows for bottom-up processes.

A conceptual HPD model for a temperate forested headwater network is shown in figure 5. Beaver impoundments and meadows are explicitly included at the segment scale, in accordance with the following criteria (Frissell et al. 1986, Poole 2002): (a) they are often hundreds of meters in length; (b) they are equivalent in length to the distance of one tributary confluence to another (e.g., see figure 2 in Poole 2002), although confluences are often within the beaver-created segments rather than at the longitudinal limits; (c) their component element boundaries are "set by inundation frequency and duration" (Poole 2002, p. 646); and (d) large beaver dams act similarly to the segment boundary of major falls (Frissell et. al. 1986, p. 203), with upstream features constrained laterally by valley walls. Since long-lasting impoundments persist for

\begin{tabular}{|c|c|c|c|c|c|c|}
\hline \multirow{2}{*}{$\begin{array}{l}\text { water- } \\
\text { tight dam } \\
\text { not } \\
\text { releasing } \\
\text { water }\end{array}$} & $\begin{array}{l}\text { intact } \\
\text { beaver } \\
\text { dam }\end{array}$ & $\begin{array}{c}\text { glacially } \\
\text { scoured } \\
\text { depression }\end{array}$ & $\begin{array}{r}\text { brea } \\
\text { sedime }\end{array}$ & & $\begin{array}{c}\text { lateral } \\
\text { bedrock } \\
\text { constriction }\end{array}$ & $\begin{array}{r}\text { concrete- } \\
\text { lined } \\
\text { channel }\end{array}$ \\
\hline & \multicolumn{2}{|c|}{$\begin{array}{l}\text { bedrock } \\
\text { knob }\end{array}$} & $\begin{array}{l}\text { breached } \\
\text { beaver dam }\end{array}$ & \multicolumn{2}{|c|}{$\begin{array}{l}\text { debris } \\
\text { dam }\end{array}$} & riffle \\
\hline \multicolumn{6}{|c|}{ Discontinuous } & Continuous \\
\hline
\end{tabular}

Figure 4. Examples of features along a river corridor on a gradient from discontinuous to continuous, where the entirely continuous feature allows all water and sediment to flow through the cross section unmodified, and the discontinuous feature blocks all water and sediment flow. Each of the feature types provided here as an example has a range along this gradient depending on factors such as the size, materials, and condition of the feature. 


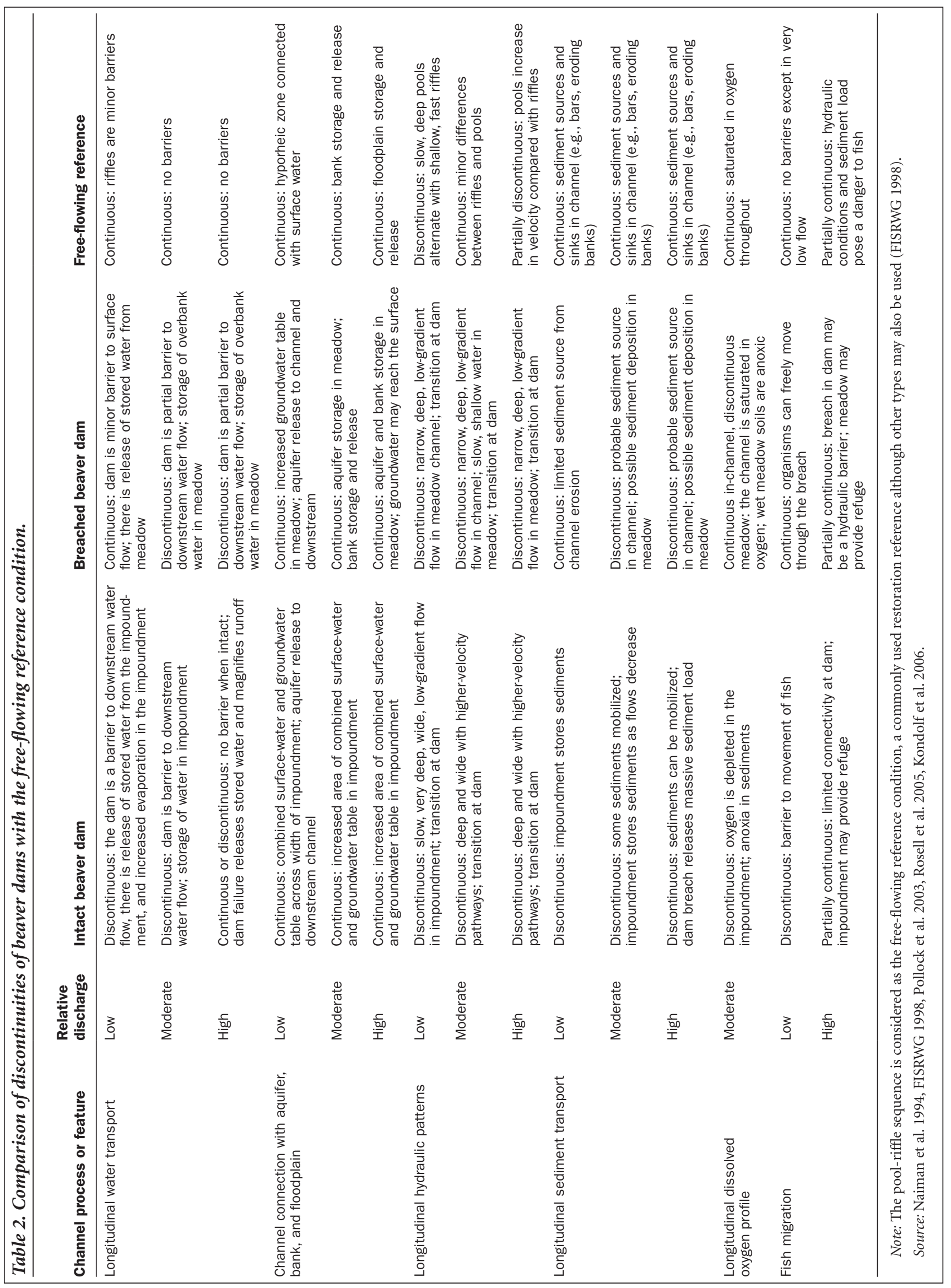




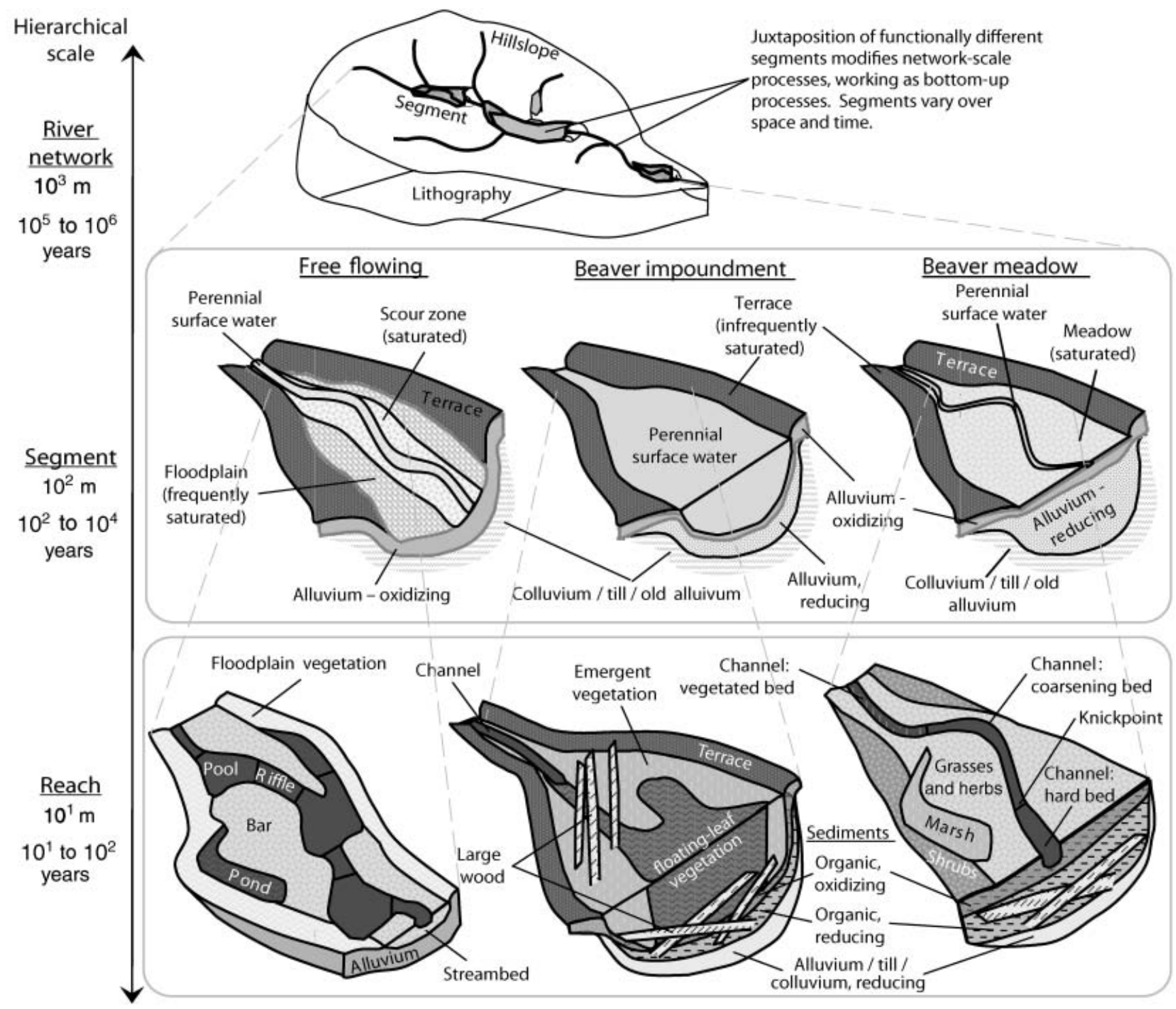

Figure 5. Schematic of a hierarchical patch dynamics perspective (Wu and Loucks 1995, Poole 2002) of the forested headwater system, which explicitly includes features created by beavers. Each row represents a different scale perspective of the same landscape. Continuing smaller scales (e.g., habitat, microhabitat) are not shown here. Examples of patch types at each scale are provided only as examples. It is possible to view the system in numerous ways and many important patch types (e.g., beaver dams at reach scale) are not shown. Patches or elements at the same scale are linked by within-scale processes. Encompassing elements at larger scales provide top-down context for component elements at smaller scales.

centuries, and beaver-created wetlands remain for centuries to millennia (Naiman et al. 1988), we propose that the segment time scale include hundreds of years to accommodate the relevant biological and geological factors (figure 5).

At the smaller reach scale, the size and nature of patches depend on the type of encompassing element. For example, separate $10-$ to $100-\mathrm{m}$ long channel patches (reaches) may not exist in impounded segments, where the surface water patch can extend for much of the length of the impoundment (Johnston and Naiman 1987). If the elements at this scale are more broadly defined as acting at the $10-$ to $100-\mathrm{m}$ scale in one or more dimensions, and as component elements of a segment, component reach-scale elements can be defined by vegetation, inundation, oxygenation, and lithographic zones, as shown in table 3 .

The addition of oxygenation zones to the patch element types previously presented in the literature is essential to a discussion of reference headwater processes for restoration. Alternating aerobic and anaerobic segments affects numerous biogeochemical cycles at the network scale, of which carbon and nitrogen are especially notable.

\section{Headwater segment descriptions}

We explicitly define the following three primary headwater segment types: free flowing, beaver impoundment, and beaver meadow (see figure 1 for examples). Beaver 


\begin{tabular}{|c|c|c|c|}
\hline \multirow[b]{2}{*}{ Direction of view } & \multicolumn{3}{|c|}{ Segment type } \\
\hline & Free flowing & Beaver impoundment & Beaver meadow \\
\hline \multicolumn{4}{|l|}{ Longitudinal } \\
\hline Segment component & Channel reach & Inundation and vegetation zones & Channel reach \\
\hline Boundaries & $\begin{array}{l}\text { Geologic discontinuities; debris and } \\
\text { sediment dams }\end{array}$ & $\begin{array}{l}\text { Inundation zones: water depth and } \\
\text { inundation frequency and duration, as } \\
\text { controlled by beaver dam height and } \\
\text { condition and by impounded sediment } \\
\text { Vegetation zones: inundation zones and } \\
\text { ecological factors }\end{array}$ & $\begin{array}{l}\text { Wood and sediment remains from } \\
\text { earlier beaver activity; knickpoints } \\
\text { from headward-progressing erosion }\end{array}$ \\
\hline \multicolumn{4}{|l|}{ Lateral } \\
\hline Segment component & Inundation zones & Inundation and vegetation zones & Inundation and vegetation zones \\
\hline Boundaries & $\begin{array}{l}\text { Inundation frequency and duration, } \\
\text { as controlled by channel morphology } \\
\text { and valley topography }\end{array}$ & $\begin{array}{l}\text { Inundation zones: water depth and } \\
\text { inundation frequency and duration, as } \\
\text { controlled by beaver dam height and } \\
\text { condition and by impounded sediment } \\
\text { Vegetation zones: inundation zones and } \\
\text { ecological factors }\end{array}$ & $\begin{array}{l}\text { Inundation zones: water depth and } \\
\text { inundation frequency and duration, as } \\
\text { controlled by channel morphology, valley } \\
\text { microtopography, and remnant dams } \\
\text { Vegetation zones: inundation zones } \\
\text { and ecological factors }\end{array}$ \\
\hline \multicolumn{4}{|l|}{ Vertical } \\
\hline Segment component & Aquifer zones & Oxygenation and aquifer zones & Oxygenation and aquifer zones \\
\hline Boundaries & Lithologic boundaries & $\begin{array}{l}\text { Oxygenation zones: dissolved oxygen } \\
\text { levels in the water column and } \\
\text { sediments }\end{array}$ & $\begin{array}{l}\text { Oxygenation zones: dissolved oxygen } \\
\text { levels in soil porewater }\end{array}$ \\
\hline & & Aquifer zones: lithologic boundaries & Aquifer zones: lithologic boundaries \\
\hline
\end{tabular}

impoundment boundaries are set by surface water limits as impounded by a beaver dam. Beaver meadow boundaries are set by the limit of saturated sediment created by a failed beaver dam. Free-flowing segment boundaries are set by significant geomorphic constrictions or beaver-segment limits. Each of these segment types is described in further detail below, and a summary of key structure and function parameters is presented in table 4 .

Free flowing. Free-flowing streams are described by a robust body of literature. The numerous forms of this segment type in headwaters include bedrock, colluvial, cascade, step pool, plane bed, pool riffle, and dune ripple systems (Montgomery and Buffington 1997), all of which generally have a zero to positive net sediment export. These channels are oxygenated, and water and sediment transport are coupled (Church 2002), although transport can be decoupled by reworked glacial deposits, bedrock obstructions, colluvial sediment inputs, and large woody debris (Montgomery 1999). The stream banks of the free-flowing segment are forested, maintaining lower water temperatures and providing critical organic inputs to the stream. The resulting in-stream community, as characterized by the RCC, includes macroinvertebrates that fundamentally depend on the organic matter supplied by the riparian forest. Fisheries management of this segment type is often focused on trout and salmon (Salmonidae spp.) populations.

Beaver impoundment. A beaver impoundment is a previously free-flowing river segment flooded by a beaver dam. Although new dam locations can be unpredictable, the ultimate success of these dams depends on water reliability (sensu Howard and Larson 1985) as well as food availability. In particular, lower stream gradients improve beaver colony successand presumed longevity of the impoundment - as well as increasing the amount of impounded sediments (Howard and Larson 1985, Persico and Meyer 2009). Additional major water reliability parameters include low percentage of well-drained soils, high watershed size, and high stream width (Howard and Larson 1985).

Once the impoundment is successfully established, it is characterized by large dead wood, either standing or fallen; low water velocities; and accumulated fine-grained and organic sediments (Pollock et al. 2003). Relative to freeflowing segments, the channel is deeper at the dam (though it can be much shallower in the upper reaches of the larger impoundments because of sediment accumulation) and the higher riparian groundwater table supports littoral marshes. The combination of slow water and high productivity results in low oxygen concentrations in the water column (Snodgrass and Meffe 1998) and in the sediments, which can become 


\begin{tabular}{|c|c|c|c|}
\hline Stream parameter & Free flowing & Beaver impoundment & Beaver meadow \\
\hline Channel shape & Lower sinuousity & Pond & Higher sinuousity \\
\hline Normal width & Moderately narrow & $\begin{array}{l}\text { In-channel dam: narrow } \\
\text { Valley dam: wide }\end{array}$ & Narrow \\
\hline Normal depth & Shallow & Shallow to deep & Moderately shallow \\
\hline Bankfull width & Moderately wide & Moderately to very wide & Moderately wide \\
\hline Bankfull depth & Moderate & Moderately shallow to deep & Moderate \\
\hline Floodplain width & Narrow & Narrow & Wide \\
\hline Channel bed material size & $\begin{array}{l}\text { Gravel to boulder, with gravel } \\
\text { or sand deposition (embedded) }\end{array}$ & $\begin{array}{l}\text { Organic, with layers of gravel } \\
\text { or fines }\end{array}$ & $\begin{array}{l}\text { Unsorted, with scattered } \\
\text { cobbles on surface }\end{array}$ \\
\hline Segment-scale sediment transport & Stable or erosional & Depositional & Erosional \\
\hline $\begin{array}{l}\text { Reach-scale sediment transport: } \\
\text { erosion }\end{array}$ & $\begin{array}{l}\text { Bar migration; channel widening; } \\
\text { entrenchment; scouring downstream } \\
\text { of dams }\end{array}$ & $\begin{array}{l}\text { Riparian burrowing and canal } \\
\text { construction }\end{array}$ & $\begin{array}{l}\text { Channel entrenchment; } \\
\text { armoring }\end{array}$ \\
\hline $\begin{array}{l}\text { Reach-scale sediment transport: } \\
\text { deposition }\end{array}$ & $\begin{array}{l}\text { Bar migration; channel narrowing } \\
\text { or filling }\end{array}$ & Pond bottom sedimentation & Off-channel sedimentation \\
\hline Canopy & Closed & Open & Open or closed \\
\hline Organic matter $(\mathrm{OM})$ source & Riparian forest & Macrophyte and autotroph & Riparian macrophyte \\
\hline Dissolved oxygen & High to saturated & Low to zero & $\begin{array}{l}\text { Channel: high } \\
\text { Riparian: low }\end{array}$ \\
\hline Redox potential & High & Low to negative & Low to high \\
\hline OM storage stock/accumulation rate & Low/negative & High/high & High/unknown \\
\hline Instream temperature & Cool & Warm & Cool to warm \\
\hline Functional feeding groups & Shredders, filterers & Collectors, predators, filterers & Unknown \\
\hline
\end{tabular}

Note: Normal width and depth exceeded approximately 50\% of the time.

Source: Naiman et al. 1988, 1994, Johnston et al. 1995, Pollock et al. 2003.

entirely anoxic (Naiman et al. 1988), creating a net storage of organic nitrogen and carbon that is many times that of comparable free-flowing segments (Naiman et al. 1986). Beaver impoundments support entirely different communities than free-flowing reaches (cf. Rosell et al. 2005) because of higher summer water temperatures, lower oxygen levels, and deposition of fine grains and organic sediments. Though often thought to replace cool-water fish habitat with warmwater habitat (e.g., Müller-Schwarze and Sun 2003), beaver impoundments improve cool-water fisheries at the network scale in the large majority of site studies (Pollock et al. 2003).

This segment type can be subdivided into two distinct categories according to the width of the dam (Pullen 1971). The valley impoundment is created by a dam that extends beyond the free-flowing river channel, often impounding the valley bottom to the break in slope at the valley wall. These segments contain thick deposits of impounded sediments. In contrast, the in-channel impoundment is created by a beaver dam constrained by the bankfull channel. It can contain a range of sediment transport conditions from deposition to erosion. These dams are commonly found in series downstream of larger valley dams, and have a much shorter life span (Pullen 1971). Both types of impoundments can be further classified according to the age and condition of the dam (e.g., Pullen 1971, Snodgrass and Meffe 1998).
Beaver meadow. A beaver meadow is created following the breach of a beaver dam. An old dam is commonly overgrown with shrubs, with a clearly defined channel exiting through a breach. Normal flows are contained within a defined, sinuous channel (Naiman et al. 1994) formed in the impounded sediments through headward-progressing erosion that begins at the breach in the dam. Despite its sinuous form, depositional features that would indicate active channel meandering are absent. Rather, the channel cuts downward into unconsolidated impounded sediments, with near-vertical or undercut banks. The channel bed is unsorted, with scattered large cobbles on the surface indicating a coarsening process associated with removal of finer particles from the bed (figure $1 b$ ).

Beyond the channel banks, the meadow is vegetated with shrubs, grasses, sedges, and wetland herbs, distributed in patches according to the level of saturation as well as other ecological factors (e.g., Terwilliger and Pastor 1999). Meadows can be classified broadly according to the presence or absence of a shrub overstory (Wright et al. 2002), and along a gradient according to age of the meadow, which corresponds with the duration of inundation (Wright et al. 2003). The canopy is often closed over the channel in a shrub meadow. In an open meadow, grasses and sedges on the banks may provide some shading and organic inputs (Menninger and Palmer 2007). 
Temporal variability of segments. In conjunction with spatial variability (figure 5), any given headwater segment will also change over time, a characteristic inherent in modifications by ecological engineers such as beavers (Stanford et al. 2005). The amount of time a modified habitat retains its characteristics and the rate of transition to another segment type depend on the speed with which the system recovers from an engineer-imposed modification. In the case of beavers, the sequence begins with construction of a dam, which converts a free-flowing segment to an impounded segment within years. The resulting impoundment generally persists for years to decades, although some last for centuries (Naiman et al. 1988, Wright et al. 2002). An abandoned dam can last for decades before being fully breached and generating the defined channel that completes the transition from impoundment to beaver meadow (Snodgrass and Meffe 1998). After a beaver meadow forms, it transitions from young and wet to old and moist (Naiman et al. 1994, Wright et al. 2002). The meadow then persists for centuries (Wright et al. 2002), and can transition into wetland features that remain for centuries to millennia (Naiman et al. 1988).

Although it is hypothesized that beaver meadows transition back to free-flowing segments in mature forests (e.g., Naiman et al. 1988), observations of this complete transition are generally lacking (Wright et al. 2004). This dearth of observation may be a result of long transition times that outlast the research time scale, although some late-successional streams have been observed (Bartel et al. 2010). The lengthy transition time is in spite of adjacent seed sources, and is partly a result of the lack of ectomycorrhizal fungi in meadow sediment (Terwilliger and Pastor 1999). Additionally, the most familiar form of the single-thread, free-flowing segment type may be a relict of postcolonial straightening of wetland streams that were the fully recovered form of beaver impoundments. Regardless, the cycle can begin anew with new dams constructed in beaver meadows or free-flowing segments.

Given the time scales of persistence, it seems likely that beaver meadows dominate the riverscape under baseline conditions. Exploring this sequence with a patch-dynamics model, Wright and colleagues (2004) predicted that continually active impoundments require a source of beavers to recolonize following predation, disease, or other loss. In catchments without this source, the river network may undergo repeated cycles of colonization and dam abandonment, resulting in a dominance of meadow segments over time.

\section{Future research needs and implications for restoration}

Beaver dams are an example of the many discontinuities that generate sources and sinks in the longitudinal profile of sediment and water flux. Given the importance of these physical parameters to ecological function, it is imperative to understand these impacts at the catchment scale for successful restoration (Palmer 2009). The conceptual model presented in this article is intended to frame research questions to address this need.

These research questions can be summarized as follows: How does a spatially and temporally discontinuous system affect the processes most commonly addressed by river restoration projects? Using the analysis of river restoration priorities by Bernhardt and colleagues (2005), the commonly addressed processes of restoration can be lumped into the categories of natural-flow regime, channel geomorphology (including sediment transport regimes and channel form), water quality, and biota. Known and hypothesized specifics of the impacts of beaver dams on these processes are presented below as an example of analysis of a river network that is patchy and punctuated by discontinuities.

Additionally, the conceptual model emphasizes that spatial variability resulting from longitudinal discontinuities cannot be seen until the perspective is extended beyond the reach scale. We expect that serial discontinuities would cause reachand segment-scale process modifications to affect catchmentscale processes (Ward and Stanford 1983). Therefore, a second research question is: What are the cumulative impacts of nonhuman, predisturbance longitudinal discontinuities on river processes when considered at network-and larger-scales? Therefore, the following discussions consider the potential impact of beaver dams on processes at this scale.

Lastly, there is a need to apply ecological advances beyond the RCC to river restoration by asking: How can restoration projects accommodate our understanding of rivers as patchy systems punctuated by physical discontinuities? Although we stress that much more research must be completed in order to understand the previous two research questions, and to properly envision the baseline condition for restoration, we also note that there may be opportunities to test this understanding with on-the-ground restoration. Therefore, we conclude this section with potential prototype restoration projects that could be implemented to test a system's response when serial beaver dam discontinuity is considered at the catchment scale.

Beavers and the natural flow regime. Beaver-generated discontinuities impound water under high flows, which is stored as both surface- and groundwater (cf. Pollock et al. 2003). The potential impacts of these discontinuities at the catchment scale are best considered within the framework of the natural flow regime (sensu Poff et al. 1997), which encompasses the magnitude of flow during average and extreme events, as well as the timing, duration, frequency, and rates of change of flow rate during ecologically significant periods such as droughts and floods. Beaver activity alters the flow regime by enhancing surface storage and groundwater recharge, which presumably increase baseflows, reduce drought duration and frequency, and increase duration of high flows. Although baseflow rates rise in some beaver-colonized systems, others fall, potentially the result of greater evaporation from impoundments or increased transpiration from the riparian forest (e.g., Burns and McDonnell 1998). The impact of beaver colonization on baseflows may also be controlled by the underlying aquifer's ability to store and release groundwater recharged by the impoundment.

The impact of beaver activity on storm flow rates, in contrast, depends on antecedent conditions. In wet conditions, higher groundwater levels increase the saturated source 

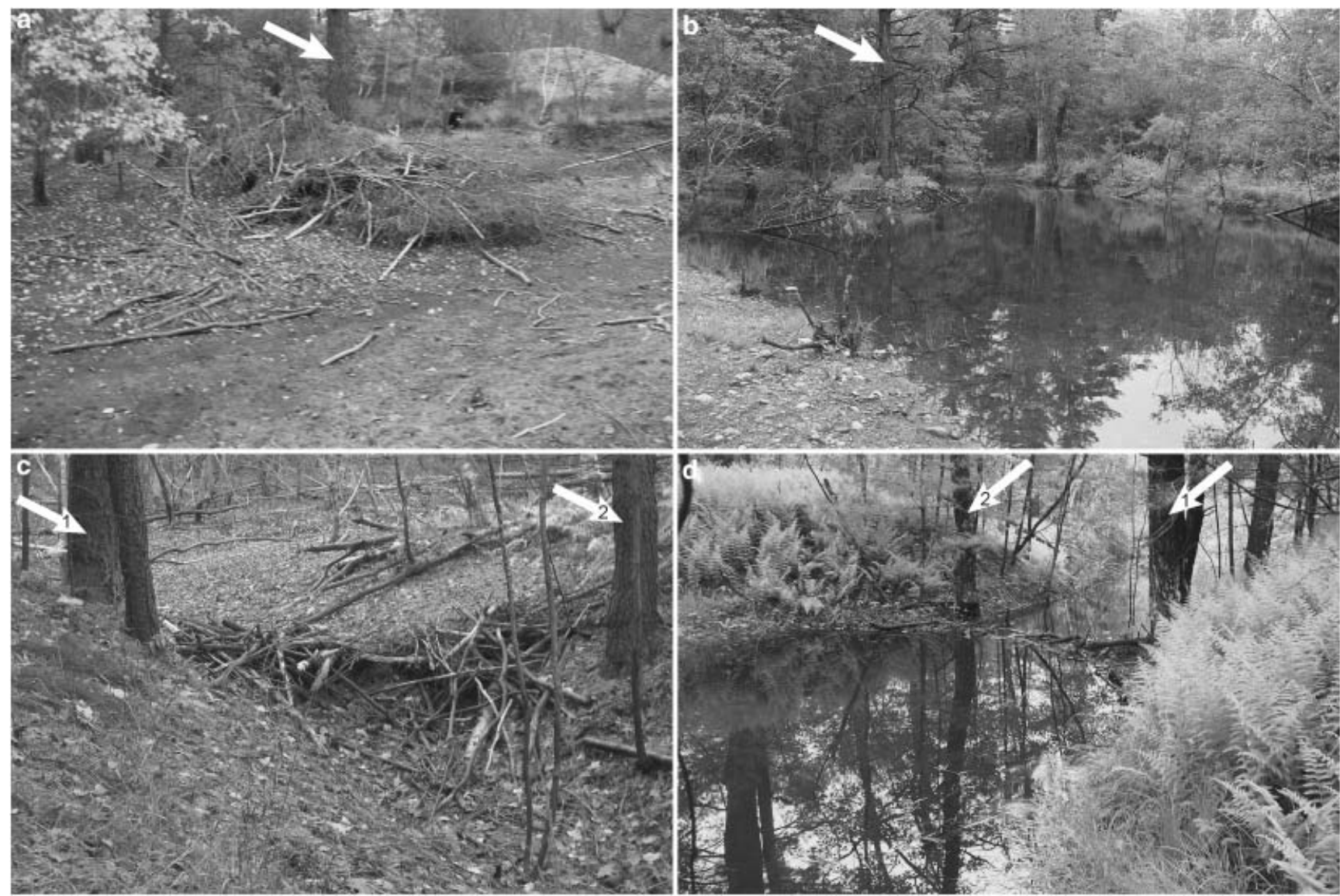

Figure 6. Example of modification of the natural flow regime by beaver dams in a beaver-colonized network in northeastern Connecticut during drought (October 2007: [a] and [c]) and high flow (May 2008: [b] and [d]). Panels (a) and (b) show similar locations, as do panels (c) and (d). Arrows provide reference points for comparisons. In all panels, flow is to the right. During drought conditions, the available storage in the network could retain the runoff of a 10-year rainfall, as estimated by the rational method. A rain event during high flows, however, as in the right panels, would result in increased runoff from the greater saturated surface area in comparison with the network without beaver colonization.

area, which can increase storm runoff. In dry conditions, beaver ponds can store runoff and decrease downstream peak flow rates (Rosell et al. 2005). Figure 6 provides a comparison of beaver ponds under wet and dry antecedent conditions. However, large storm events overwhelm the impacts of the beaver pond, with no difference detected between an impoundment outlet stream and a comparable free-flowing stream (Burns and McDonnell 1998). If a storm causes a beaver dam to fail, the peak flow rate can be greatly enhanced by the resulting flood wave, which may cause dam failures in series downstream (Butler and Malanson 2005). A dam's ability to withstand storm flows depends on its condition, controlled by factors such as beaver food availability, predation, and tunneling in the dam by other animals.

Therefore, we hypothesize that beaver dams increase the complexity of storm response and result in a higher level of stochastic variability at the decadal time scale. Overall, for any given catchment, we hypothesize that the impact of beaver activity on the natural flow regime of a catchment depends on the relative abundance of each segment type, on the ability of the aquifer to store and release water, and on the climate.

Beavers and channel geomorphology. We hypothesize that the three primary headwater segment types differ fundamentally in both channel morphology and in process, and that these differences affect the sediment budget of a catchment. Processes associated with sediment regime differ at the segment scale, with overall deposition in impoundments, erosion in meadows, and transport or erosion in free-flowing segments. Of these sediment regimes, deposition in impoundments is sufficient to create riparian landforms that persist centuries to millennia and modify the landscape at the network scale (Ives 1942, Naiman et al. 1988, Butler and Malanson 2005).

Although less quantified than deposition, beaver-induced erosion also shapes the fluvial corridor. In addition to erosion in meadows described in the previous section, burrow and canal excavation by beavers also generates erosion (Butler 1995). Erosion is not limited to areas upstream of beaver dams; it can also occur downstream, and may be 
confined to the predam channel. Valley dams, additionally, often have multiple spillways, eroding new channels and creating a multiple-thread reach downstream (Burchsted et al. 2009). The river may also spill over the dam to an entirely new location, eroding a new channel while the dam blocks the old one, creating a channel avulsion (John and Klein 2004). A further source of erosion is catastrophic erosion of impounded sediments caused by dam failure. Although this has not been well studied in beaver dams, transport of sediments in the event of human dam failure can be modeled as a sediment wave with a braided channel form that is transported downstream (Doyle et al. 2002).

Therefore, we hypothesize that the sediment wave released from the failure of a beaver dam would eventually create a braided deposit at the head of the next downstream impoundment. Further, the creation and later stochastic failure of dams would create a river system characterized by impoundments, meadows, and wetlands with multithread channels, where the multithread channels would be created both by sediment wave deposition from upstream impoundments and by erosion downstream of active dams. This predicted form is similar to the precolonial form retrodicted by Walter and Merrits (2008), set within a sequence of beaver meadows such as those described by Ives (1942).

Examination of modern beaver-colonized catchments suggests a net accumulation of sediments. Depositional segments can be up to $1000 \mathrm{~m}$ long and 10 to $100 \mathrm{~m}$ wide. In comparison, nonimpoundment erosional segments are rarely $100 \mathrm{~m}$ in length, with the width of a free-flowing channel. Since most impounded material remains in the meadows, it appears that the net balance would be sediment accumulation. Stratigraphic analysis by Persico and Meyer (2009), however, found less than $2 \mathrm{~m}$ of accumulation in most beaver meadows, despite the record of more than 4000 years of beaver activity in their study area. We hypothesize that the net impact of recent beaver colonization is accumulation of sediments. As the availability of ideal habitat decreases and impoundments fill in, however, the rate of accumulation presumably decreases. Therefore, we hypothesize that the total catchment sediment output would be slightly lower overall than currently estimated without beavers, with lower output under most flows, but much increased peak sediment load over the time scale of decades as a result of stochastic sediment releases.

Although beaver meadows are erosional, most of the previously impounded sediments remain in place (Butler and Malanson 2005) and the channel banks are often nearly vertical, suggesting that the sediment is more stable than transport theory would predict. We propose three mechanisms that would promote sediment stability in beaver meadows: (1) the sediments are located within and on top of a matrix of large wood derived from the preimpoundment canopy, creating a segment-long debris dam; (2) increased nutrient availability and fluctuating water levels-and the corresponding large littoral zone-encourage macrophyte growth that stabilizes sediments; and (3) sediment particles are bound by microbial secretion of extracellular polymeric substances, which are found in freshwater ecosystems at levels similar to those that bind marine sediments enough to resist intertidal wave energy (Gerbersdorf et al. 2008).

Beavers and water quality. Beaver activity fundamentally modifies biogeochemical cycling at the network scale by creating reducing environments (Naiman et al. 1994, Johnston et al. 1995) in comparison with the oxidizing environments of free-flowing segments. When these segment types alternate, beaver ponds provide sites of denitrification (Correll et al. 2000). In spite of greater denitrification, nitrogen inputs to the beaver pond may nonetheless be higher than in the corresponding free-flowing segment because of both beaver foraging and impounding of forest stands as well as dramatically increased microbial fixation of nitrogen in beaver ponds (Collen and Gibson 2000). When comparing beaver ponds and free-flowing segments in catchments enriched with nitrogen, however, beaver ponds decrease nitrogen. Beaver ponds and meadows also have higher $\mathrm{pH}$ levels (Naiman et al. 1994) and bolster buffering capacity in acidic catchments (Collen and Gibson 2000). Therefore, we hypothesize that under beaver-dominated baseline conditions, nitrogen concentrations at the network scale were higher than in modern free-flowing conditions with limited modern human impact. Beaver colonization of modern nutrient-enriched catchments, however, is expected to lower overall nutrient concentrations. We further hypothesize that beaver-colonized catchments are more resistant to fluctuations in nutrient inputs when compared with free-flowing catchments.

Temperature is an important water quality component for salmonids-a critical target group for many restoration projects-that require cool-water refugia in summer and warmwater refugia in winter. Beaver ponds tend to increase water temperatures in summer, although in winter the impacts appear to be site specific (Collen and Gibson 2000). These surface-water impacts affect temperatures in groundwater (Lowry 1993) and corresponding downstream baseflow. We hypothesize that a catchment with early colonization by beavers undergoes increased surface-water temperatures in summer, but this increase dissipates over time as impoundments transition to meadows. Downstream temperature impacts of impoundments may be offset in part by the time lag between surface-water temperature increase and increases in groundwater down-gradient; Lowry (1993) measured a three-month lag. Additionally, early summer temperatures in impoundments may remain cool near the bottom as a result of increased riparian groundwater inputs.

Beavers and biota. Overall, beaver-created features are more productive than free-flowing segments. The communities associated with each of the three headwater segment types are distinct, with similar richness but different species compositions. Network-scale diversity of macroinvertebrates (McDowell and Naiman 1986) and riparian herbs (Wright et al. 2002) increases when all three segment types are present in a network where beavers are native. The inclusion of 
beavers in a network can also increase the presence of rare species that depend on transient habitat (Bartel et al. 2010).

Fish species richness is greater in beaver impoundments and meadows (Pullen 1971, Snodgrass and Meffe 1998), and fishes associated with beaver impoundments are larger and more abundant (cf. Pollock et al. 2003). Additionally, endemic fish species - many of which are imperiled — are often found in headwaters, and are driven by niche specialization largely attributable to geographic isolation (Magurran 2009). By creating additional channel network complexity, including ponds and marshes laterally separate from the main channel, beavers may play a role in the creation and maintenance of fish biodiversity. Therefore, we hypothesize that, where beavers are native, beaver-colonized networks have enhanced species richness and increased presence of rare species. Modern recolonization by beavers, however, could alter existing habitats used by rare species and push them toward extirpation.

Beaver colonization creates feeding, rearing, and refuge habitat for fish, and can even create new habitat where populations were previously unviable (Collen and Gibson 2000, Pollock et al. 2003). At marginal sites, however, beavers can negatively affect salmonid populations through higher temperatures, increased barriers to migration, and decreased spawning site availability (Collen and Gibson 2000). Fisheries managers often remove beaver dams to ensure longitudinal connectivity for migration of diadromous fish. Although beaver dams are at least temporary blockages, they typically do not prevent migration (Pollock et al. 2003). Knowing that the baseline condition includes both migratory fish and beavers, the following mechanisms are proposed to allow their coexistence: (a) most beaver dams may be passable under high flows occurring at some point during the migration period, (b) high flows during the migration period may erode or activate side channels that allow fish passage, and (c) higher straying rates of fish that spawn in headwaters allow more individuals to use nonnatal streams when compared with higher fidelity large-river spawners. This higher straying rate facilitates recolonization of streams when beaver dams are breached (e.g., Ayllon et al. 2006).

We hypothesize, therefore, that migratory fish runs are rarely limited by habitat conditions in catchments colonized by beavers, and that fish runs usually increase in these areas. However, given the depressed abundances of many native diadromous fish runs, we advise a catchment-specific approach where increased stream temperature or temporary migration barriers may devastate a given fish population.

Restoration implications. Given the level of research needed to understand the cumulative impacts of discontinuities on network-scale processes, it is premature to dramatically alter river restoration practice. Nonetheless, prototype projects designed using the concepts in this article could test some of these hypotheses as well as improve our ability to reach restoration targets. At the most fundamental level, we recommend improving habitat heterogeneity at the network scale. One possibility is to increase wet meadow habitats, which could be done by designing dam-removal projects using beaver meadows as the reference. Other options include capitalizing on existing human discontinuities such as culverts to outright creation of discontinuity at the base of a designed meadow through excavation upstream or construction of a partial barrier downstream.

Although impoundment habitat is rarely considered missing from most catchments because of the dominance of human dams, these dams and their impoundments differ from beaver dams and impoundments (e.g., table 1). Of the parameters described in table 1 , crest geometry could be altered to provide some complexity in the hydraulic cross section, allowing for variable water levels upstream and larger littoral zones. This type of modification could be designed on the basis of the practice of notching dam spillways to provide fish passage to downstream fish ladders or other structures. In managed dams, the upstream water level could be managed to allow for seasonal and climatic variability in water levels that is more similar to a beaver pond. Installation of low-flow release structures at run-of-the-river dams could further provide some of this variability. Overall, human impoundments can play an active role in watershedbased management plans, and alteration of operations to meet nutrient management goals could be considered.

Of the major processes discussed above in the context of a discontinuous river network, sediment transport may be the one that most contradicts both the restoration and the regulatory reference condition. Although the restoration reference typically considers baseline sediment regimes to be free flowing, the environmental regulatory view is typically to forbid any sediment release. The discontinuous river network, however, has both sources and sinks of sediments. Patchy storage of sediment is a fundamental part of this system, with unexplored ecological implications. Conversely, erosion of portions of these sediments is also a part of the baseline system. In-channel wetlands appear to serve a critical function within this process for retention and release of sediments, and should not necessarily be viewed as features that require protection from these processes.

\section{Conclusion}

In order to create sustainable, ecologically based restoration (sensu Palmer 2009), the paradigm of the forested headwater system must include precolonial fluvial and riparian discontinuities, including those created by beavers. The currently used reference of a purely free-flowing river provides little large-scale heterogeneity in comparison with the precolonial system that included frequent-though usually incompletebarriers to water and sediment flow. The current reference allows for none of the structure and functions associated with the once-dominant beaver ponds and meadows. Until human society can accommodate landscapes that are spatially and temporally dynamic, with entire river valleys that are seasonally saturated or impounded, it is necessary to settle for lessthan-full restoration in populated areas. A moderate level of restoration that allows for some patch heterogeneity (Naiman 
and Rogers 1997) and some of the discontinuity-generated processes can be provided by human engineering, particularly by emphasizing in-channel wetland restoration. There is great opportunity to strengthen diversity and improve functions within our river systems by considering the discontinuous reference when designing projects, and to rely on human engineering only where it is not possible to reintroduce the original river ecosystem engineer.

\section{Acknowledgments}

Discussions with Gene E. Likens, Glenn S. Warner, James G. MacBroom, Frederick D. Day-Lewis, Robert J. Naiman, and David L. Post, and comments from three anonymous reviewers, greatly improved this manuscript. Funds to DB include US Environmental Protection Agency (EPA) STAR Research Assistance Agreement FP916872 and University of Connecticut Center for Environmental Science and Engineering fellowship. This publication has not been formally reviewed by the EPA. The views expressed in this article are solely those of the authors; the EPA does not endorse any products or commercial services mentioned. DB is grateful for field assistance from Regina A. Graziano and Zibigniew J. Grabowski, site access in Yale-Myers Forest, and formative conversations with Richard K. Moynihan, William Stallman, and Mark B. Carabetta.

\section{References cited}

Ayllon F, Moran P, Garcia-Vazquez E. 2006. Maintenance of a small anadromous subpopulation of brown trout (Salmo trutta L.) by straying. Freshwater Biology 51: 351-358.

Ballantyne CK. 2002. Paraglacial geomorphology. Quaternary Science Reviews 21: 1935-2017.

Bartel RA, Haddad NM, Wright JP. 2010. Ecosystem engineers maintain a rare species of butterfly and increase plant diversity. Oikos 119: 883-890.

Benda L, Poff NL, Miller D, Dunne T, Reeves G, Pess GR, Pollock MM. 2004. The network dynamics hypothesis: How channel networks structure riverine habitats. BioScience 54: 413-427.

Benda L, Hassan MA, Church M, May CL. 2005. Geomorphology of steepland headwaters: The transition from hillslopes to channels. Journal of the American Water Resources Association 41: 835-851.

Bernhardt ES, et al. 2005. Synthesizing U.S. river restoration efforts. Science 308: 636-637.

Burchsted D, Daniels MD, Thorson RM. 2009. Including beavers in the river restoration baseline. Geological Society of America Abstracts with Programs 41: 102.

Burns DA, McDonnell JJ. 1998. Effects of a beaver pond on runoff processes: Comparison of two headwater catchments. Journal of Hydrology 205: 248-264.

Butler DR. 1995. The geomorphic influence of beavers. Pages 148-182 in Butler DR, ed. Zoogeomorphology: Animals as Geomorphic Agents. Cambridge University Press.

Butler DR, Malanson GP. 2005. The geomorphic influences of beaver dams and failures of beaver dams. Geomorphology 71: 48-60.

Church M. 2002. Geomorphic thresholds in riverine landscapes. Freshwater Biology 47: 541-557.

Collen P, Gibson RJ. 2000. The general ecology of beavers (Castor spp.), as related to their influence on stream ecosystems and riparian habitats, and the subsequent effects on fish: A review. Reviews in Fish Biology and Fisheries 10: 439-461.

Correll DL, Jordan TE, Weller DE. 2000. Beaver pond biogeochemica effects in the Maryland coastal plain. Biogeochemistry 49: 217-239.
[CTDEP] Connecticut Department of Environmental Protection. 2000. Beaver (Castor canadensis). CTDEP Bureau of Natural Resources, Wildlife Division.

Doyle MW, Stanley EH, Harbor JM. 2002. Geomorphic analogies for assessing probable channel response to dam removal. Journal of the American Water Resources Association 38: 1567-1579.

[FISRWG] Federal Interagency Stream Restoration Working Group. 1998. Stream Corridor Restoration: Principles, Processes, and Practices. National Technical Information Service. GPO Item no. 0120-A.

Frissell CA, Liss WJ, Warren CE, Hurley MD. 1986. A hierarchical framework for stream habitat classification: Viewing streams in a watershed context. Environmental Management 10: 199-214.

Gerbersdorf SU, Jancke T, Westrich B, Paterson DM. 2008. Microbial stabilization of riverine sediments by extracellular polymeric substances. Geobiology 6: 57-69.

Howard RJ, Larson JS. 1985. A stream habitat classification system for beaver. Journal of Wildlife Management 49: 19-25.

Ives RL. 1942. The beaver-meadow complex. Journal of Geomorphology 5: 191-203.

John S, Klein A. 2004. Hydrogeomorphic effects of beaver dams on floodplain morphology: Avulsion processes and sediment fluxes in upland valley floors (Spessart, Germany). Quaternaire 15: 219-231.

Johnston CA, Naiman RJ. 1987. Boundary dynamics of the aquatic-terrestrial interface: The influence of beaver and geomorphology. Landscape Ecology 1: 47-57.

Johnston CA, Pinay G, Arens C, Naiman RJ. 1995. Influence of soil properties on the biogeochemistry of a beaver meadow hydrosequence. Soil Science Society of America Journal 59: 1789-1799.

Jones CG, Lawton JH, Shachak M. 1994. Organisms as ecosystem engineers. Oikos 69: 373-386.

Junk WJ, Bayley PB, Sparks RE. 1989. The flood pulse concept in riverfloodplain systems. Pages 110-127 in Dodge DP, ed. Proceedings of the International Large River Symposium. Department of Fisheries and Oceans Canada.

Kondolf GM, et al. 2006. Process-based ecological river restoration: Visualizing three-dimensional connectivity and dynamic vectors to recover lost linkages. Ecology and Society 11: 5 .

Lichatowich JA. 1999. Salmon without Rivers: A History of the Pacific Salmon Crisis. Island Press.

Lowry MM. 1993. Groundwater elevations and temperature adjacent to a beaver pond in central Oregon. Master's thesis. Oregon State University, Corvallis.

Magurran AE. 2009. Threats to freshwater fish. Science 325: 1215-1216.

McDowell DM, Naiman RJ. 1986. Structure and function of a benthic invertebrate stream community as influenced by beaver (Castor canadensis). Oecologia 68: 481-489.

Menninger HL, Palmer MA. 2007. Herbs and grasses as an allochthonous resource in open-canopy headwater streams. Freshwater Biology 52: 1689-1699.

Meyer JL, Strayer DL, Wallace JB, Eggert SL, Helfman GS, Loenard NE. 2007. The contribution of headwater streams to biodiversity in river networks. Journal of the American Water Resources Association 43: 86-103.

Montgomery DR. 1999. Process domains and the river continuum. Journal of the American Water Resources Association 35: 397-410.

Montgomery DR, Buffington JM. 1997. Channel-reach morphology in mountain drainage basins. Geological Society of America Bulletin 109: 596-611.

Müller-Schwarze D, Sun L. 2003. The Beaver: Natural History of a Wetlands Engineer. Cornell University Press.

Naiman RJ, Rogers KH. 1997. Large animals and system-level characteristics in river corridors. BioScience 47: 521-529.

Naiman RJ, Melillo JM, Hobbie JE. 1986. Ecosystem alteration of boreal forest streams by beaver (Castor canadensis). Ecology 67: 1254-1269.

Naiman RJ, Johnston CA, Kelley JC. 1988. Alteration of North American streams by beaver. BioScience 38: 753-762.

Naiman RJ, Pinay G, Johnston CA, Pastor J. 1994. Beaver influences on the long-term biogeochemical characteristics of boreal forest drainage networks. Ecology 75: 905-921. 
Palmer MA. 2009. Reforming watershed restoration: Science in need of application and applications in need of science. Estuaries and Coasts 32: 1-17.

Palmer MA, Menninger HL, Bernhardt E. 2010. River restoration, habitat heterogeneity and biodiversity: A failure of theory or practice? Freshwater Biology 55: 205-222.

Persico L, Meyer G. 2009. Holocene beaver damming, fluvial geomorphology, and climate in Yellowstone National Park, Wyoming. Quaternary Research 71: 340-353.

Pizzuto JE. 2002. Effects of dam removal on river form and process. BioScience 52: 683-691.

Poff NL, Hart DD. 2002. How dams vary and why it matters for the emerging science of dam removal. BioScience 52: 659-668.

Poff NL, Allan JD, Bain MB, Karr JR, Prestegaard KL, Richter BD, Sparks RE, Stromberg JC. 1997. The natural flow regime: A paradigm for river conservation and restoration. BioScience 47: 769-784.

Pollock MM, Heim M, Werner D. 2003. Hydrologic and geomorphic effects of beaver dams and their influence on fishes. American Fisheries Society Symposium 37: 213-233.

Poole GC. 2002. Fluvial landscape ecology: Addressing uniqueness within the river discontinuum. Freshwater Biology 47: 641-660.

Pringle CM, Naiman RJ, Bretschko G, Karr JR, Oswood MW, Webster JR, Welcomme RL, Winterbourn MJ. 1988. Patch dynamics in lotic systems: The stream as a mosaic. Journal of the North American Benthological Society 7: 503-524.

Pullen TM. 1971. Some effects of beaver (Castor canadensis) and beaver pond management on the ecology and utilization of fish populations along warm-water streams in Georgia and South Carolina. PhD dissertation. University of Georgia, Athens.

Rosell F, Bozser O, Collen P, Parker H. 2005. Ecological impact of beavers Castor fiber and Castor canadensis and their ability to modify ecosystems. Mammal Review 35: 248-276.

Schumm S. 1977. The Fluvial System. Wiley.

Snodgrass JW, Meffe GK. 1998. Influence of beavers on stream fish assemblages: Effects of pond age and watershed position. Ecology 79: 928-942.

Stanford JA, Ward JV. 1993. An ecosystem perspective of alluvial rivers: Connectivity and the hyporheic corridor. Journal of the North American Benthological Society 12: 48-60.
Stanford JA, Lorang MS, Hauer FR. 2005. The shifting habitat mosaic of river ecosystems. Verhandlungen der Internationalen Vereinigung für Theoretische und Angewandte Limnologie 29: 123-136.

Terwilliger J, Pastor J. 1999. Small mammals, ectomychorrhizae, and conifer succession in beaver meadows. Oikos 85: 83-94.

Thorson RM. 2009. Beyond Walden: The Hidden History of America's Kettle Lakes and Ponds. Brown Walker Press.

Vannote RL, Minshall GW, Cummins KW, Sedell JR, Cushing CE. 1980. The river continuum concept. Canadian Journal of Fisheries and Aquatic Science 37: 130-137.

Walter RC, Merritts DJ. 2008. Natural streams and the legacy of waterpowered mills. Science 319: 299-304.

Ward JV, Stanford JA. 1983. The serial discontinuity concept of lotic ecosystems. Pages 29-42 in Fontaine TD, Bartell SM, eds. Dynamics of Lotic Ecosystems. Ann Arbor Scientific Publishers.

Wohl E. 2005. Compromised rivers: Understanding historical human impacts on rivers in the context of restoration. Ecology and Society 10: 2 .

Wright JP, Flecker AS, Jones CG. 2002. An ecosystem engineer, the beaver, increases species richness at the landscape scale. Oecologia 132: 96-101.

2003. Local vs. landscape controls on plant species richness in beaver meadows. Ecology 84: 3162-3173.

Wright JP, Jones CG, Gurney WSC. 2004. Patch dynamics in a landscape modified by ecosystem engineers. Oikos 105: 336-348.

Wu J, Loucks OL. 1995. From balance of nature to hierarchical patch dynamics: A paradigm shift in ecology. Quarterly Review of Biology 70: 439-466.

Denise Burchsted (denise.burchsted@uconn.edu) is a doctoral candidate at the University of Connecticut, in Storrs. She studies fluvial geomorphology and stream ecology, and has designed river restoration projects as a professional engineer. Melinda Daniels is a fluvial geomorphologist and associate professor at Kansas State University, in Manhattan, Kansas. Robert Thorson and Jason Vokoun are a surficial geologist and a professor, and a fisheries ecologist and an associate professor, respectively, at the University of Connecticut. 